\title{
THE EFFECT OF ORGANIZATIONAL CLIMATE, FATIGUE, STRESS AND MOTIVATION ON THE PERFORMANCE OF LECTURERS IN STIE WIDYA GAMA LUMAJANG.
}

\author{
Istichomah ${ }^{1)}$ \\ Imam Suroso2) \\ Muhaimin Dimyati3) \\ Higher Education of Economic Mandala \\ Email : Eksarahma@gmail.com
}

\begin{abstract}
This study aimed to test the influence of organizational climate, fatigue, stress and motivation on the performance of lecturers in STIE Widya Gama Lumajang. Likewise to know which variable between organizational climate, job burnout, stress and motivation that has dominant influence on the performance of STIE Widya Gama Lecturer in Lumajang. So, it can be used as reference materials for research in the field of human resource management, especially for improving the performance of lecturers. Based on the analysis of each variable has fulfilled a standard rate of $5 \%$ significance. Therefore, the results also showed the Organization Climate should be developed so that the leader is able to provide a conducive climate of organizational effectiveness communication policy level and the level of participation of lecturer has been good. As for variable of motivation identifies the average lecturer's needs provided by STIE Widya Gama Lumajang is still less for daily needs while the performance of lecturers have not been able to utilize the time as well as if there is a time that is loose and loose so that the utilization of time in work can se used maximally. And what needs to be noted is that the issue of devotion to sc y needs to be clearly defined and well organized.
\end{abstract}

Keyword: Organizational Climate, Fatigue, Stress, Motivation, Lecturers system

\section{INTRODUCTION}

In order to maintain STIE Widya Gama Lumajang managed to compete in the world of education and stay in the community environment in conducting tri dharma college, of course it needs to pay attention to the motivation of lecturers. The motivation of the lecturer can not be separated from the organizational climate effect that prevailed in the institution. Under these conditions an organization is required to support the expectations of lecturers, where lecturers expect rewards on the basis of their perceptions of organizational climate.

STIE Widya Gama Lumajang has the vision to achieve public recognition as the best predicate university in Lumajang city, which deserves to be regarded as a favorite university that is able to grow, excel and trust based on the potential of academic people who are knowledgeable, faithful and devout. the vision is certainly required a professional and qualified lecturers. 
The main mission of the college is to develop, transfer and apply knowledge through the experience of tri dharma college. Therefore any decision regarding college mission must involve lecturers. Besides, as a lecturer as well as a researcher and disseminator of information. The reputation of the lecturers is not only assessed on the achievement of teaching, but also the reputation of the scale, such as the presentation of papers and seminars, writing articles in scientific journals and the compilation of qualified books.

In connection with the performance of lecturers, based on pre-survey there can be said there is no significant improvement, possibly caused by the organizational climate that is too conducive for lecturers to improve their work performance, the differences in attitude that lead to different behavior, the fulfillment of the lecturers need not evenly, the encouragement of the leadership to improve the performance of lecturers, the quality of the work of some lecturers who have not been optimal, during teaching hours lecturers came late or go home early, there are lecturers who cannot cooperate with other lecturers in teaching and learning process and there are lecturers who teach is not in accordance with schedules that have been determined the existence of work fatigue and the stress of lecturers.

During this coaching is done periodically through the briefing at the coordination meeting at the beginning of the semester, monitoring and evaluation of the work at the end of the semester, but this system has not covered all aspects of activities that can describe the performance of lecturers. The evaluation of the results of coaching programs and follow-up has not been implemented optimally, so the impact of this program on the performance of lecturers is not yet known. (1986,197) organizational climate variables develop a satisfactory instrument on the behavioral conditions and management styles used. Characteristics covered by Likert scale are leader behavior, motivation, communication, interaction effect process, decision making, goal setting, and control.

From the phenomenon, the problem is not optimum performance of lecturers at STIE Widya Gama Lumajang which can be influenced by several factors, including organizational climate, work fatigue, stress and motivation of lecturers.

Based on the background and the importance of the role of universities in realizing the creation of qualified human resources, the organizational climate, stress work fatigue and work motivation and performance evaluate the results of the guidance and follow-up program has not been implemented optimally, so the impact of this program on the performance of lecturers has not known yet.

This study was conducted to determine the cause of less optimum lecturer performance of STIE Widya Gama Lumajang which can be influenced by several factors such as organizational climate, work fatigue, stress and motivation of lecturer.

The reason researchers conduct a study of lecturer's performance of STIE Widya Gama Lumajang as to determine the effect of organizational climate or human environment within the organization 
that later became the culture of the organization, so whether it is true that the question is the environment, whether how to lead, how to work, work fatigue, stress and motivation simultaneously, partially and variable which most dominant influence to lecturer performance at STIE Widya Gama Lumajang. Likewise research results can provide theoretical contributions of existing knowledge in the development of the field of human resource management. Lumajang in an effort to improve lecturer's performance through organizational climate, work fatigue, stress on motivation of lecturer's performance.

From the phenomenon that becomes a problem is not yet optimal lecturer performance in STIE Widya Gama Lumajang which can be influenced by several factors such as organizational climate, work fatigue, stress and motivation of lecturers is a topic that should be scientifically researched, so researchers interested to conduct research with the title " The Influence of Climate Organization, Work Fatigue, Stress and Motivation on Lecturer Performance at STIE Widya Gama Lumajang ".

\section{RESEARCH METHOD}

The object of this research is the relation between fact and climate of organization, work fatigue, stress and motivation to performance. While the subject of research is the lecturer of STIE Widya Gama Lumajang, which consists of lecturers of foundations who have served at least 5 years.

This research is explanatory research that explains the relationship between one variable of other variable (Singarimbun, 1989), in this case the influence of organizational climate of work fatigue, stress and motivation to lecturer performance through hypothesis testing that has been formulated previously. The research is observation using survey by taking sample of all foundation lecturers at STIE Widya Gama Lumajang private university and using questionnaire as main data measuring instrument. In this study population is eluruhan lecturer in high school economics STIE Widya Gama Lumajang as many as $\mathbf{5 0}$ people, taken as respondents 37 lecturers.

Identification of variables based on the formulation of hypotheses, which will be analyzed, grouped into three types as follows: 1. Independent Variable: organizations Climate (X1) Work Fatigue (X2) and Stress (X3).

2. Dependent Variable: motivation (Y1)

3. Intervening variables: Performance (Y2)

Operational definition of research variables as follows:

1. Organizational Climate (X1), organizational climate as a measurable characteristic of work environment prepared directly or indirectly by people living and working in the environment and assumed to influence their motivation and behavior.

Variable indicators are: organization policy and regulation, level of communication effectiveness, level of relationship between employee and employee participation level.

2. Variable X2, work fatigue i weakening Activity Weakening Motivation, Physical Weakness

3. Variable X3, Stress is a condition of tension that affects the ability of a person who can interfere with the implementation of their work.

4. Variable Y1 Motivation is a source of motivation to work lecturers in carrying out the tasks assigned to him. 
5. Variable Y2, Lecturer Performance is a performance pointed to the ability of lecturers in completing tasks that are charged in accordance with empirically determined standards with indicators as stated in SK MenKOWASBANGPAN No 38 / Kep / MK DESCRIPTION / 8/99 About functional positions and credit numbers teaching positions of tri dharma education colleage.

Data Collection Method prepared to get valid and reliable data, hence researcher use questionnaire method, interview, documentation. The measurement scale used in the research is the Likert scale with the assessment interval for each respondent's answer is 1 to 5 . The answer interval will be adjusted to the question asked. Likert Scale is used to measure the attitudes, opinions and perceptions of respondents to the research object.

Data Analysis Methods include Validity and reliability test, Classical Assumption test, Multicolinearity test, normality test, linearity test, Heteroskidastity test.

\section{RESULTS ANALYSIS}

The results of the analysis are presented in the following table

Tabel 1

Results SPSS Statistics To collinearity coefficients

\begin{tabular}{|c|c|c|c|c|c|c|c|c|}
\hline \multirow{2}{*}{\multicolumn{2}{|c|}{ Model }} & \multicolumn{2}{|c|}{$\begin{array}{l}\text { Unstandardized } \\
\text { Coefficients }\end{array}$} & \multirow{2}{*}{\begin{tabular}{|c}
$\begin{array}{c}\text { Standardi } \\
\text { zed } \\
\text { Coefficien } \\
\text { ts }\end{array}$ \\
Beta
\end{tabular}} & \multirow[b]{2}{*}{$\mathrm{T}$} & \multirow[b]{2}{*}{ Sig. } & \multicolumn{2}{|c|}{$\begin{array}{l}\text { Collinearity } \\
\text { Statistics }\end{array}$} \\
\hline & & B & $\begin{array}{l}\text { Std. } \\
\text { Error }\end{array}$ & & & & $\begin{array}{c}\text { Tolera } \\
\text { nce }\end{array}$ & VIF \\
\hline \multirow[t]{3}{*}{1} & (Constant) & 47.395 & 4.170 & & 11.36 & .000 & & \\
\hline & $\begin{array}{l}\text { Stres Kerja } \\
\text { (X3) }\end{array}$ & -.270 & .228 & -.220 & 2.183 & .047 & .890 & 1.124 \\
\hline & $\begin{array}{l}\text { Kelelahan } \\
\text { Kerja (X2) }\end{array}$ & -.500 & .328 & -.283 & 2.525 & .039 & .890 & 17 \\
\hline
\end{tabular}

a. Dependent Variable:

Kinerja dosen $(\mathrm{Y})$,

Table 2 Test Results Multicolinearity

\begin{tabular}{|c|c|c|c|}
\hline Variabel & Tolerance & VIF & Keterangan \\
\hline Stres (X3) & 0 & 1,124 & Bebas Multikolinearitas \\
\hline Kelelahan kerja (X2) & 0 & 1,124 & Bebas Multikolinearitas \\
\hline
\end{tabular}


Table 3. Data Sources: Questionnaire Results Data Processing with SPSS

Table 4.Hasil Regression Test variables X and Y "ANOVA"

a.Predictors: (Constant), MOTIVATE (Y1), STRESS (X3), FATIGUE WORK (X2) CLIMATE ORGANIZATION (X1)

b.Dependent Variable: PERFORMANCE LECTURER (Y2)

\begin{tabular}{|c|c|c|c|c|c|c|}
\hline \multirow[t]{2}{*}{ MODEL } & \multicolumn{2}{|c|}{$\begin{array}{l}\text { Unstandart } \\
\text { rized } \\
\quad \text { Coefficient } \\
\end{array}$} & \multirow{2}{*}{$\begin{array}{l}\text { Stndarized } \\
\frac{\text { Coefficients }}{\text { Beta }}\end{array}$} & \multirow[t]{2}{*}{$\mathrm{T}$} & \multirow[t]{2}{*}{ Sig } & Collie \\
\hline & B & $\begin{array}{l}\text { Std. } \\
\text { Eror }\end{array}$ & & & & Tole \\
\hline $\begin{array}{l}\text { 1.(CONSTANT) } \\
\text { IKLIM } \\
\text { ORGANISASI } \\
\text { MOTIVASI }\end{array}$ & $\begin{array}{r}1.291 \\
.461 \\
.136\end{array}$ & $\begin{array}{l}433 \\
.125 \\
.084\end{array}$ & $\begin{array}{l}.522 \\
.230\end{array}$ & $\begin{array}{l}2.977 \\
6.695 \\
3.629\end{array}$ & $\begin{array}{l}.005 \\
.000 \\
.001\end{array}$ & \\
\hline Model & $\begin{array}{l}\text { Sum of } \\
\text { Square } \\
\text { S }\end{array}$ & Df & $\begin{array}{c}\text { Mean } \\
\text { Square }\end{array}$ & $\mathrm{F}$ & Sig & \\
\hline $\begin{array}{l}1 \text { Regression } \\
\text { Residual } \\
\text { Total }\end{array}$ & $\begin{array}{l}1.036 \\
1.584 \\
2.620\end{array}$ & $\begin{array}{c}2 \\
33 \\
35\end{array}$ & $\begin{array}{l}.518 \\
.048\end{array}$ & 10.792 & & $000^{a}$ \\
\hline
\end{tabular}

t variables and the dependent variable

Model Summaryb

\begin{tabular}{|c|c|r|r|r|r|}
\hline Model & $\mathrm{R}$ & R Square & $\begin{array}{c}\text { Adjusted } \\
\text { R Square }\end{array}$ & $\begin{array}{c}\text { Std. Error } \\
\text { of the } \\
\text { Estimate }\end{array}$ & $\begin{array}{c}\text { Durbin-W } \\
\text { atson }\end{array}$ \\
\hline 1 & $.851^{\mathrm{a}}$ & .724 & .697 & .21909 & 1.1411 \\
\hline
\end{tabular}

a. Predictors: (Constant), MOTIVATE (Y1),), STRESS (X3), FATIGUE WORK (X2) CLIMATE ORGANIZATION (X1)

b. Dependent Variable: PERFORMANCE LECTURER (Y2)

Data source: processed in 2016

According to the table 1,2,3,4 and 5, the models in the form diagrampath path coefficient test results are presented in Figure 1. 




$\mathrm{X}_{3.2}$ RETATION

1. researches on organizational climate variables in STIE Widya Gama Lumajang known that the implementation of organizational climate has been running well, it can be seen in general score for the organizational climate variable rate indicator Policies and Regulations organizations is $3.22 \%$, further indicators of the level effectiveness of communicat known to score the average is 3.42 , indukator level known relationship between the lecturers the average score was 4.06, an indicator of participation known lecturer its average score was 3.2, the descriptive statistics obtained from its average value is 3.58 , it can be said that the implementation of the organizational climate in Lumajang Widya Gama STIE has been running well. Organizational climate can provide a life dynamics in organizations and influence on the human resources (La Follete, 1975 in Suyanto, 2007). Elements such as attitudes, values and individual motives has an important role in the process of conceptual organizational climate. Thus it can be concluded that organizational climate is a characteristic that describes the environment in organizational psychology that indicates the content and the strength of the influence of values, norms, attitudes, behaviors and feelings of members of the organization.

2. researches on variable working Fatigue is lowered working capacity and endurance work is characterized by the sensation of fatigue, decreased motivation, decreased activity. Results of respondents to kelelahankerja. Validity test results be valid if a minimum count $r 0.3$ or $r$ count larger than $r$ table. It can be concluded that not all the questions on job burnout variables dinyatakanvalid. Thus there are some the questions that exist in this 
research instrument that can not be declared eligible as a research instrument because it can not collect data or information that is better, then in this case do retesting by eliminating the questions that have been declared invalid.

3. researches on variable tension Stress is a condition that affects the emotions, thought processes and the person's condition in which he is forced to give a response beyond the capability of adjusting itself to an external demands (environment). Responses of respondents can be seen that the variable stress, have an average response of 2.32 to the value of the highest average response of 3.80 to the statement "The job requires me to be resolved soon.". The average value of the lowest 1.30 at the statement " I do not understand clearly the responsibility that is my duty. "With an average value of 2,23, this indicates that the assessment of the Stress variable has a high value trend, indicating that Stes is an important thing to be aware of and avoided when they want to give good performance to STIE Widya Gama Lumajang.

4. Research on variables Motivation of research results partially indicate that the results of this study is different from the results of research Saiful (2003) and research results Ida fatmawati (2007) where the dominant variable in both of them there is motivation, while the results of research conducted by researchers now is climate organization, the difference of these findings also identifies that the different places of study will also produce different variables of influence. The result of research know that work motivation about related to Aldefer theory which bases itself on requirement of individual requirement from theory can we see in general score variable for each indicator variable that is indicator of existence need with value average is 2,97 or just $59,4 \%$ who feel the level of existence needs are met. Indicator of dependent relationship variable is 4.16 or $83.2 \%$ means that the level of relevance is good, then the growth needs indicator produces an average score of 3.2 or $63.57 \%$ is still considered sufficient,

5. Research on Lecturer Performance variables in STIE Widya Gama Lumajang known that the achievement of lecturer's performance has been running well, it can be seen in general score of performance indicators of education and teaching indicators known average score of 4.10 next research indicator known average score 3.6 indicator of community service is known to the average score is 3.59 from the descriptive statistics it can be said that the achievement of lecturer's performance has been achieved and has been running well where the score of 3.96 or close to average 4 thus the performance has been said the category of good, but need to get attention related to community service during the last three years need improvements and programmed and structured well.

6. The findings of this study are organizational climate is already conducive to the indicator of policy level and organizational regulation, the level of communication 
effectiveness and level and level of lecturer's participation, but for the item of question the leader is still considered to be less listening and being somewhat closed to suggestions and reports from lecturers, and the leadership is still less helpful to provide solutions to the problem of work.

\section{CONCLUSION}

Based on the results of data analysis and interpretation it can be concluded that the Climate Organization must be developed, ie with a leader who is able to provide a conducive climate from the level of organizational effectiveness and the level of participation of the lecturer is good. While for the variable of motivation to identify / show the average of lecturer requirement given by STIE Widiagama Lumajang still less for everyday requirement whereas lecturer performance has not been able to utilize the time as well as good if there is a time that is loose and loose so that the utilization of time in work can not in maximum use. And also need attention is the issue of dedication to the community needs to be in the program clearly and well compiled.

The results of the first hypothesis testing that examined the effect of job stress on lecturer performance showed that job stress had a negative effect on the performance of STIE lecturer Widya Gama Lumajang. This means that work stress increases the lecturer's performance will decrease and work stress decreases the lecturer's performance will increase. The results of testing on work stress and work fatigue simultaneously on the performance of lecturers, showed that simultaneously over work stress and work fatigue have a significant effect on performance. The result of testing on job stress and work fatigue simultaneously on lecturers' performance shows that simultaneously over job stress and work fatigue have a significant effect on performance. This research also gives result that independent variable which dominant influence to lecturer performance.

\section{IMPLICATIONS}

Based on the conclusion of the research result, it can be obtained the implication of this research, that is as follows for STIE Widyagama Lumajang, from the findings of this research result, where the organizational climate and motivation berkruh to the performance of lecturers, it is suggested to remain in the organizational climate as a planner, and as a coach associated with the improvement of the achievement of the appropriate work program in canangkan.Distribusu frequency fariabel motifasi produce lower value in comparison with organizational climate fariabel value. low value fariabel this motifasi haurs in strive to increase good attitude behavior through penydaran and keaktif and discipline and also the increase in salaries and benefits, Climate indicator value Organization of the leadership always helps provide solutions to the problems of work can be said less, therefore need to strive for the creation of a good communication network for all peke rjaan. Can be done well and can reach tujan from organization. As for the motivation that needs to be improved is that lecturers can take advantage of spare time and can use the time as well as possible for the things that are useful and the increase in salaries and allowances on 
average salaries and benefits are considered less.

The end result of this research is to improve the performance of lecturers STIE Widya Gama Lumajang then organizational climate should be

\section{REFERENCES}

Ambar T, 2001, Manajemen Sumber Daya Manusia, Konsep Teori dan Pengembangan dalam Konteks Organisasi, Edisi pertama, Graha IImu, Yoyakarta.

Anwar P M,2001Manajemen Sumber Daya Perusahaan,Cetakan Kelima. PT Remaja Rosda Karya, Bandung .

Anwar P M,2007 Evalasi Kinerja Smberdaya Daya Manusia, Cetakan Ketiga,PT Remaja Rosda Karya, Bandung.

Andriyani, N urita, 2002, Pengruh Iklim Organisasi dan Kepuasan Kerja tehadap Kinerja Karyawan, Ju Aplikasi Manajemen, Vol 2 NO 1,Aprı 2004

As ad, Muhammad (1995), Perilaku Kaorganisasian, Jakarta, Al Rasyid H, 1997, Teknik Penarikan Sampel dan Penyusunan Skala, PPS Unpad, Bandung.

Arikunto, Suharsini, 2006, Prosedur Penelitian, Edisi Revisi VI, Rineka Cipta, Jakarta

Amstrong, M, 1999, Seri Pedoman Manajemen, Manajemen Sumber Daya Manusia, Alih Bahasa Sofyan Cikmat dan Haryanto, Alek Media Komputindo, Jakarta. developed while the work motivation should be improved, but work fatigue, stress must be lowered to the motivation of lecturer performance.It is in accordance with the concept of human resource development.

Anonim,2004, Pedoman Penulisan Tesis, Program Pascasarjana, Uwiga,Malang.

Batinggi, Ahmad (1999), Manajemen Sumber Daya Manusia, jung PSTMK,Jakarta.

Dharma, Agus, 1995, Manajemen Prestasi Kerja,Rajawali, Jakarta. Davis K, 1996, Perilaku Organisasi, Terjemahan Agung Darma, Erlangga, Jakarta.

Desler, G, 2006, Manajemen Sumber Daya Manusia, Terjemahan: Paramita Rahayu, PT Indeks, Jakarta.

Gibson,1998, Organisasi Perilaku, Struktur, Proses, Terjemahan: Djarkasih. Jilid II, Erangga, Jakarta

Gujarati.D, 1999, Basic Ekonometrik, New York Mc Graw Hill Kasali, Renald, 2005, Change, Gramedia, Jakarta.

Hanafi, Mamduh M, 2003, Ma 15 !n, YKP, Yogyakarta.

Harianja, Marihot Tua, Effendi,2007, Manajemen Sumber Daya Manusia, Grasindo, Jakarta.

Hasibuan, Melayu SP, 1997, Manajemen Sumber Daya Manusia, Manajemen Dan Kunci Keberhasilannya, Gunung Agung, Jakarta. 
Kossen, Stan, 1986, Aspek Manusiawi Dalam Organisasi, Erlangga, Jakarta.

Kusnanu, Akhmad, 2004, Analisis Sikap Iklim Organisasi, Etos Kerja dan

Disiplin Kerja Dalam Menentkan Effektifitas Kinerja Organisasi, Karya tulis Ilmiah, Program Pascasarjana, Unair, Surabaya.

Likert, R, 1996, Organisasi Manusia Nilai dan Manajemen, Terjemahan:Suranto, Erlangga, Jakarta

Maskun, Sumitro,1997, Pengembangan Tenaga Funsional sebagai Pendukung Peningkatan Sumberdaya Mansia, Widya Praja no 26

Tahun XVIII, IIP, Jakarta.

M. Manullang, 1981, Manajemen Sumber Daya Manusia. BPFE, Yogyakarta.

Moenir, 2000, Manajemen Pelayanan Umum di Indonesia, Bumi Aksara,Jakarta

Mutiari, Sulstyo, 2006, Pengaruh Iklim Organisasi dan Komunikasi Efektif Terhadap Kinerja Kariyawan, Tesis Program Pascasarjana Unibraw,Malang.

Ndraha, Tahziduh, 2003, Budaya Organisasi, PT Rineka Cipta, Jakarta.
Peraturan Pemerintah No 60 Tahun 1999 tentang Pendidikan Tinggi R.I. Jakarta.

Purwanti, Heny, 2003, Pengaruh Pengembangan, Komitmen dan Motivasi

terhadap Kinerja Dosen, Tesis Perogram Pascasarjana Unibraw,Malang.

Robbin, S, P, 2006 Perilaku Organisasi, Prenhalindo, Jakarta.

Rivai, Veithzal, 2005, Manajemen Sumber Daya Manusia Untuk Perusahaan,

PT Gramedia Pustaka Utama, Jakarta.

Saiful, 2005, Pengaruh Motivasi dan Iklim Organisasi Terhadap Kinerja Karyawan, Tesis Perogram Pascasarjana Uwiga, Malang.

16

Santosa dan Ciptono, 20 1 , s'PSS Mengolah Data Statistik Secara Prefesional, PT Alek Komptindo, Jakarta.

Satriyo, 1997, Pengaruh Perilaku Pemimpin, Iklim Organisasi dan Kinerja

terhadap Kepuasan Kerja, Tesis Perogram Pascasarjana Unibraw, Malang.

\section{BIOGRAPHY}

Istichomah, born in Lumajang (East Java) on February 2, 1967. The third child of four siblings, my father is alm. M.Sodiq and my mother Arofah.dua my brother Agus Iswanto and Saiful Rahman and one of my sisters Lutfiah, my husband alm.M. Afif Hidayaturohman we have six children Amilia Rahma Naimatul Aghni, Salsabila Naurah Rahma, Aghfira Ramadhani Rahma, Aisha Aulia Rahma, Exa Hidayati Rahma, M.Kaisar Rahman Al'Ala.

I started my education at Elementary School level Jogoyudan 1 Lumajang graduated in 1980, Then continued to junior Junior High School 1Lumajang graduated in 1983, Setela went to the level of SMA Negeri 2 Lumajang and graduated th 1986, Traveling 
S1 in Institute of Science and Technology Palapa Malang faculty of Technology and Informatics majoring in Industrial Technology graduated in 1991. Then pursue a career as a lecturer at STIE Widya Gama Lumajang until now. While continuing to S2 in STIE Mandala Jember Magister Management graduated in 2016. 